\title{
Evaluation of MERS-CoV Neutralizing Antibodies in Sera Using Live Virus Microneutralization Assay
}

\author{
Abdullah Algaissi and Anwar M. Hashem
}

\begin{abstract}
The microneutralization $(\mathrm{MN})$ assay is a standard and important technique in virology, immunology, and epidemiology. It is a highly specific and sensitive assay for evaluating virus-specific neutralizing antibodies (nAbs) in human and animal sera. It provides the most precise answer to whether or not an individual or animal has antibodies that can neutralize or inhibit the infectivity of a specific virus strain. However, using live virus-based $\mathrm{MN}$ assay might require working under high containment facilities especially when dealing with high-risk pathogens such as the Middle East respiratory syndrome-coronavirus (MERS-CoV). In this chapter, we describe the isolation, amplification, and titration of MERS-CoV, as well as detailed MN assay to measure $\mathrm{nAb}$ levels in sera from different mammalian species.
\end{abstract}

Key words MERS-CoV, Neutralizing antibodies, Microneutralization

\section{Introduction}

The Middle East respiratory syndrome-coronavirus (MERS-CoV) is a novel zoonotic $\beta$-coronavirus that was first identified in Saudi Arabia in 2012 [1]. Epidemiological evidence suggests that dromedary camels are the main zoonotic source of MERS-CoV $[2,3]$. MERS-CoV causes a wide range of manifestations ranging from asymptomatic infections to mild or severe respiratory disease. Detection of anti-MERS-CoV antibodies (Abs) in humans and/or animals represents a valuable tool in diagnostics as well as epidemiological, virological, and immunological studies including evaluation of vaccine immunogenicity [4-8]. Several serological assays have been developed and used for MERS-CoV, including ELISAbased assays, immunofluorescence assays, protein microarrays, and pseudovirus-based neutralization assays [9-17]. However, most of these assays pose several drawbacks and limitations such as low specificity and sensitivity, need for expensive and special equipment and reagents, and/or highly trained technical staff, which could limit their use. 
On the other hand, live virus-based microneutralization $(\mathrm{MN})$ assay is a highly sensitive and specific technique used for the quantitation of virus-specific neutralizing antibodies (nAbs) to a given virus in mammalian sera as well as the evaluation of antiviral activities of small molecules and biologics. The assay has several advantages in detecting nAbs against MERS-CoV. It can precisely detect virus-specific nAbs in human and animal sera without the need for specific reagents or equipment, it can be carried out readily once the virus is isolated, and it can overcome strain-specific antigenic changes. The protocol presented in this chapter consists of four major steps, including MERS-CoV isolation, amplification, titration, and neutralization. The MN assay described here is suitable to quantitatively measure the titer of nAbs in sera from different mammalian species.

\section{Materials}

\subsection{General Materials}

1. Vero E6 cells.

2. $37^{\circ} \mathrm{C}$ water bath.

3. Biosafety cabinet.

4. $37^{\circ} \mathrm{C}$ incubator with $5 \% \mathrm{CO}_{2}$.

5. Low-speed centrifuge.

6. Inverted microscope.

7. Cell counter or hemocytometer.

8. M-10 media: Dulbecco's modification of Eagle medium (DMEM), 10\% heat-inactivated fetal bovine serum (FBS), $1 \%$ L-glutamine, and $1 \%$ penicillin/streptomycin.

9. M-2: Dulbecco's modification of Eagle medium (DMEM), 2\% heat-inactivated fetal bovine serum (FBS), 1\% L-glutamine, and $1 \%$ penicillin/streptomycin.

10. $70 \%$ Ethanol for decontamination of laminar flow biosafety cabinet and objects brought into the hood.

11. Sterile serological pipettes.

12. Sterile DPBS without calcium or magnesium.

13. Sterile $1 \times$ trypsin-EDTA in DPBS without calcium or magnesium.

14. Sterile T25, T75, and T175 tissue culture flasks with vented caps.

15. Sterile $15 \mathrm{~mL}$ falcon tubes.

16. Sterile $1.5 \mathrm{~mL}$ tubes.

17. $1 \mathrm{~mL}$ pipette.

18. Multichannel pipette. 
2.2 MERS-CoV

Isolation, Amplification, Titration, and Microneutralization
19. Sterile disposable aerosol-resistant filtered tips.

20. Sterile $0.22 \mu \mathrm{m}, \gamma$-irradiated syringe filters.

MERS-CoV is a biosafety level 3 (BSL3) pathogen. Thus, all work involving infectious MERS-CoV should be handled in a BSL3 facility following the institutional guidelines and regulations such as wearing the proper PPE and having the proper training to work at a BSL3 facility.

1. Confluent Vero E6 cells cultured in M-10 in a T75 tissue culture flask.

2. Sterile 96-well tissue culture plates.

3. Sterile U-shaped 96-well plates.

4. MERS-CoV-positive sample: filtered using Sterile $0.22 \mu \mathrm{m}$, $\gamma$-irradiated syringe filters (to be used for virus isolation).

5. Isolated MERS-CoV (to be titrated or amplified).

6. Titrated MERS-CoV (for microneutralization assay).

7. Test serum samples.

\section{Methods}

\subsection{Continuous Culture of Vero E6 Cells}

Proper aseptic techniques should be used, and all equipment and solutions to be used with cells must be sterile. All cell culture incubations should be performed in a humidified $37{ }^{\circ} \mathrm{C}$ incubator with $5 \% \mathrm{CO}_{2}$, and all solutions should be pre-warmed to room temperature or $37^{\circ} \mathrm{C}$ before use with cells.

1. Remove a cryovial of frozen Vero E6 cells from liquid nitrogen storage and quickly thaw the cells for $<1$ min by gently swirling in a $37^{\circ} \mathrm{C}$ water bath until there is just a small bit of ice left in the vial (see Note $\mathbf{1})$.

2. Transfer the vial into a laminar flow biosafety cabinet and quickly disinfect the outside of the vial with $70 \%$ ethanol.

3. Open the vial and transfer all the volume to a sterile $15 \mathrm{~mL}$ falcon tube containing $10 \mathrm{~mL}$ of pre-warmed M-10 (see Note 2).

4. Centrifuge the cell suspension at approximately $200-500 \times g$ for $5 \mathrm{~min}$ at room temperature.

5. Aseptically decant the supernatant without disturbing the cell pellet (see Note 3).

6. Gently re-suspend the cells in $10 \mathrm{~mL}$ of pre-warmed M-10 (see Note 4).

7. Transfer the cell suspension to T75 tissue culture flask using sterile $10 \mathrm{~mL}$ serological pipette.

8. Incubate the flask in $37^{\circ} \mathrm{C}$ incubator with $5 \% \mathrm{CO}_{2}$. 


\subsection{Isolation and Amplification of MERS-CoV}

9. Monitor cells under an inverted microscope daily or every other day and change media every 3-4 days if necessary (see Note 5).

10. When cells reach $>90-95 \%$ confluency, passage cells into new tissue culture flasks at 1:5 to 1:10 split ratio (see Notes 6 and 7).

11. Maintain cells in continuous culture and passage them as needed for at least 2-3 passages after removal from long-term storage and before use.

1. Harvest confluent Vero E6 cells from a T75 tissue culture flask using standard trypsinization procedure (see Note 7).

2. Count cells using cell counter or hemocytometer and prepare a cell suspension of $5 \times 10^{5}$ cells $/ \mathrm{mL}$ in pre-warmed M-10.

3. Seed $5 \mathrm{~mL}\left(\sim 2.5 \times 10^{6}\right.$ cells $)$ or $20 \mathrm{~mL}\left(\sim 1 \times 10^{7}\right.$ cells $)$ of the cell suspension into a T25 or T175 tissue culture flask, respectively, so that they are $90-95 \%$ confluent the next day ( see Note 8).

4. Incubate the flasks in $37{ }^{\circ} \mathrm{C}$ incubator with $5 \% \mathrm{CO}_{2}$ for overnight.

5 . Next day, change the media by removing old media and add $2 \mathrm{~mL}$ or $5 \mathrm{~mL}$ of fresh pre-warmed M-2 into a T25 or T175 tissue culture flask, respectively.

6. If using positive MERS-CoV sample, filter sterilize samples using Sterile $0.22 \mu \mathrm{m} \gamma$-irradiated syringe filters before inoculation onto Vero E6 cells ( see Note 9).

7. Add $0.5-1 \mathrm{~mL}$ of isolated MERS-CoV or filtered positive sample to the cells ( see Note 10).

8. Distribute the virus evenly over the cells and incubate for $1 \mathrm{~h}$ in $37{ }^{\circ} \mathrm{C}$ incubator with $5 \% \mathrm{CO}_{2}$.

9. Make up the final volume of media to $5 \mathrm{~mL}$ or $20 \mathrm{~mL}$ in $\mathrm{T} 25$ or T175 tissue culture flasks, respectively.

10. Incubate the flask in $37^{\circ} \mathrm{C}$ incubator with $5 \% \mathrm{CO}_{2}$ for $2-3$ days or until significant cytopathic effect (CPE) is observed (Fig. 1).

11. Check the flask daily post-infection ( see Note 11).

12. When $\mathrm{CPE}$ is $>50 \%$, collect supernatant from the flask and centrifuge at $500 \times g$ for 5 min to remove cellular debris (Fig. 1).

13. Aliquot collected clarified supernatant in $100 \mu \mathrm{L}$ or $1 \mathrm{~mL}$ aliquots in sterile $1.5 \mathrm{~mL}$ tubes and store at $-80{ }^{\circ} \mathrm{C}$ ( see Note 12$)$.

1. Harvest confluent Vero E6 cells from the T75 tissue culture flask using standard trypsinization procedure (see Note 7).

2 . Count the cells using cell counter or hemocytometer and prepare a cell suspension of $1 \times 10^{5}$ cells $/ \mathrm{mL}$ in pre-warmed M-10. Re-suspend $1 \times 10^{6}$ cells in $10 \mathrm{~mL}$ per 96 -well plate. 

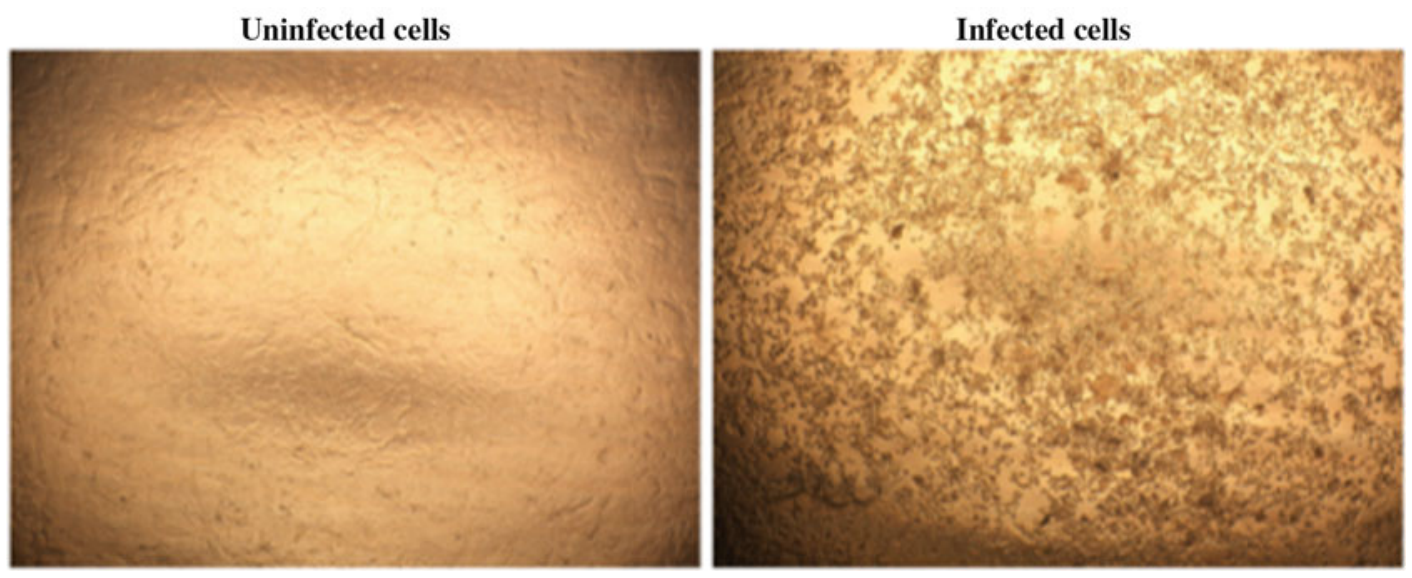

Fig. 1 Example of cytopathic effect (CPE) observed in Vero E6 cells infected with MERS-CoV 3 days after inoculation

3. Seed $1 \times 10^{4}$ Vero E6 cells $(100 \mu \mathrm{L})$ per well into sterile 96-well tissue culture plate so that they are 90-95\% confluent the next day ( see Note 8 ).

4. Incubate the plate in $37{ }^{\circ} \mathrm{C}$ incubator with $5 \% \mathrm{CO}_{2}$ for overnight.

5. Next day, in a new sterile U-shaped 96-well plate, add $135 \mu \mathrm{L}$ pre-warmed M-2 to all wells (Fig. 2).

6. Add $15 \mu \mathrm{L}$ of MERS-CoV per well in all wells of column 1 to have 1:10 dilution (Fig. 2).

7. Perform tenfold serial $(\log 10)$ dilution by transferring $15 \mu \mathrm{L}$ progressively from column to column (Fig. 2) using a multichannel pipette (see Note 13).

8. During each dilution step, mix well by pipetting eight times up and down (see Note 14).

9. Discard the final $15 \mu \mathrm{L}$ after column 11 (i.e., wells in column 12 should not contain virus, cell control (CC)).

10. Remove the 96-well tissue culture plate containing confluent Vero E6 cells and aspirate the media ( see Note 15).

11. Transfer $100 \mu \mathrm{L}$ from the U-shaped 96-well plate containing diluted MERS-CoV sample to the cells in each corresponding well in the 96-well tissue culture plate using a multichannel pipette (see Note 14).

12. Incubate the 96-well tissue culture plate in $37^{\circ} \mathrm{C}$ incubator with $5 \% \mathrm{CO}_{2}$ for 3 days (see Note 11 ).

13. After incubation, observe plate under an inverted microscope and score wells as positive for MERS-CoV (i.e., CPE) or negative for MERS-CoV (i.e., cells are intact and no CPE) (see Note 16).

14. Calculate TCID $_{50}$ using Reed-Muench formula [18]. 


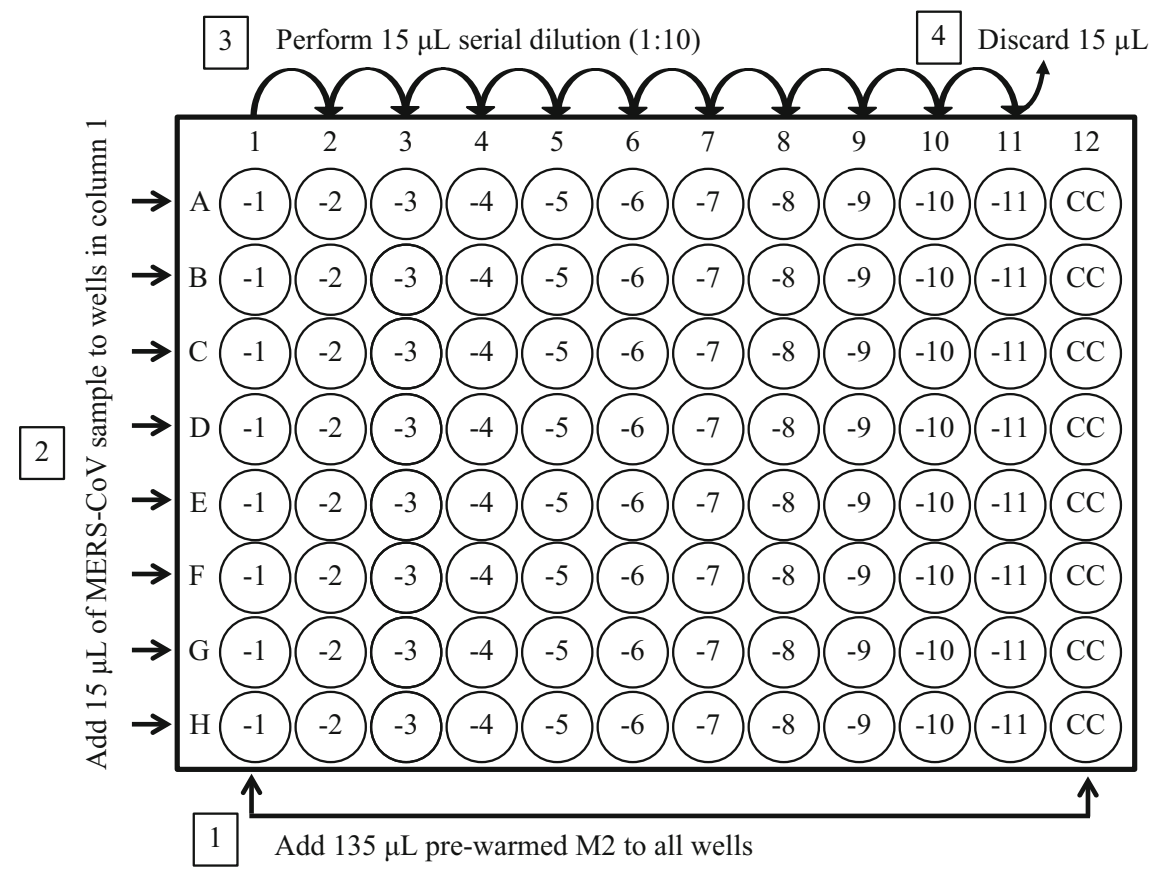

Fig. 2 Schematic representation of preparation of virus dilution for MERS-CoV titration by $\mathrm{TCID}_{50}$. The sequential steps of plate preparation are indicated by numbered boxes. After completion, transfer $100 \mu \mathrm{L}$ from the 96-well U-bottom plate containing diluted MERS-CoV sample to the cells in each corresponding well in the 96-well tissue culture plate using a multichannel pipette. CC is cell control wells

\subsection{MERS-CoV Microneutralization Assay}

1. Harvest confluent Vero E6 cells from the T75 tissue culture flask using standard trypsinization procedure (see Note 7).

2. Count the cells using cell counter or hemocytometer and prepare a cell suspension of $1 \times 10^{5}$ cells $/ \mathrm{mL}$ in pre-warmed M-10. Re-suspend $1 \times 10^{6}$ cells in $10 \mathrm{~mL}$ per 96 -well plate.

3. Seed $1 \times 10^{4}$ Vero E6 cells $(100 \mu \mathrm{L})$ per well into sterile 96-well tissue culture plate so that they are 90-95\% confluent the next day ( see Note 8 ).

4. Incubate the plate in $37^{\circ} \mathrm{C}$ incubator with $5 \% \mathrm{CO}_{2}$ overnight.

5. Next day, heat-inactivate test sera to be used for virus microneutralization by incubation for $30 \mathrm{~min}$ at $56^{\circ} \mathrm{C}$.

6 . In a new sterile U-shaped 96 -well plate, add $60 \mu \mathrm{L}$ pre-warmed M-2 to all wells (Fig. 3).

7. Add an additional $48 \mu \mathrm{L}$ pre-warmed M-2 to wells Al-Al0 in row A (Fig. 3).

8. Add $12 \mu \mathrm{L}$ heat-inactivated serum per well in wells Al-Al0 in row A to have 1:10 dilution (Fig. 3). Do not add serum to All and Al2 (see Note 17). 


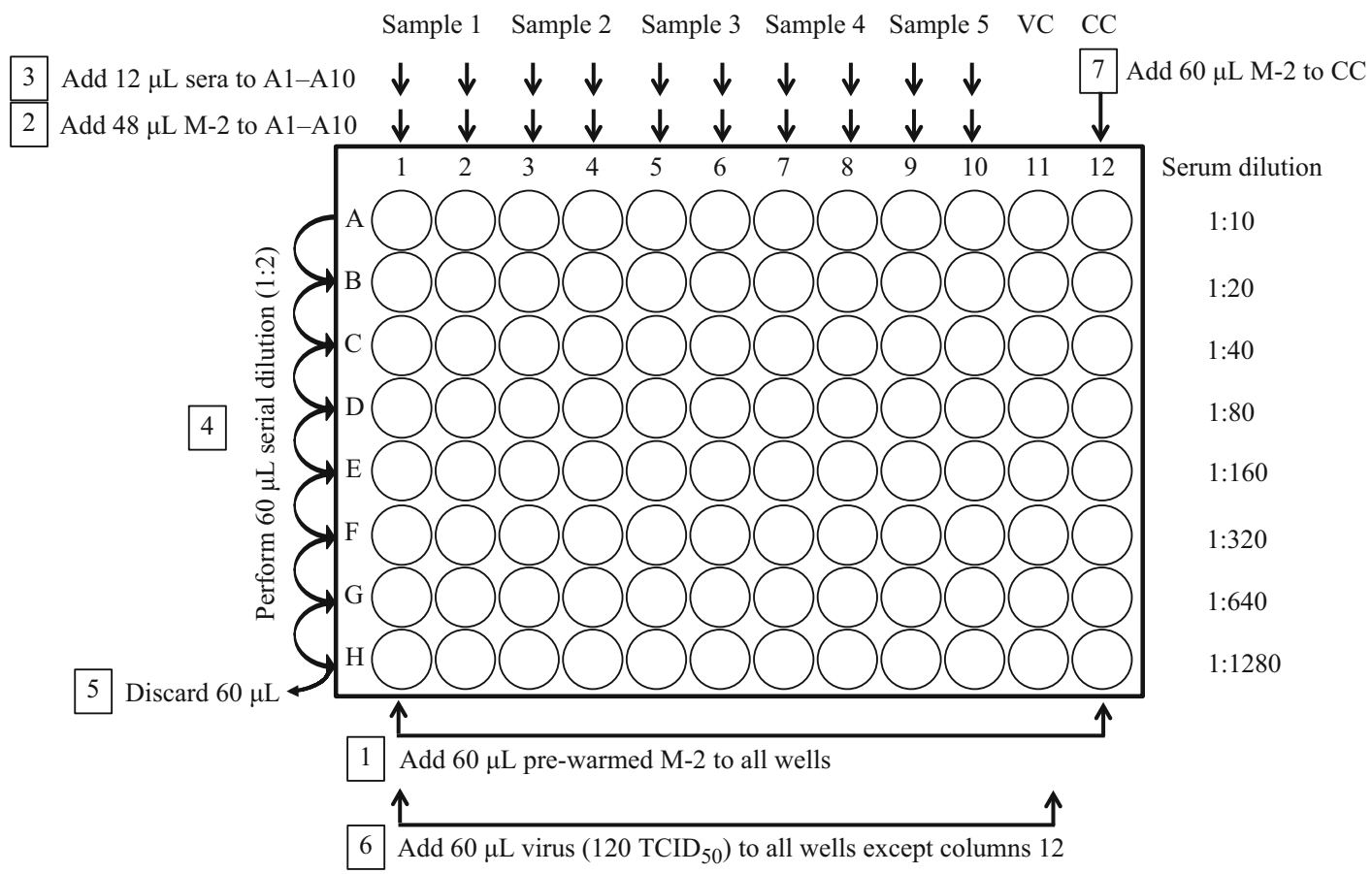

Fig. 3 Plate preparation for MERS-CoV microneutralization assay. The preparation steps for MERS-CoV microneutralization assay plate are indicated by numbered boxes. After completion, incubate the serumvirus mixtures for $1 \mathrm{~h}$ in $37^{\circ} \mathrm{C}$ incubator with $5 \% \mathrm{CO}_{2}$. Then, transfer $100 \mu \mathrm{L}$ from the U-shaped 96 -well plate containing diluted MERS-CoV sample to the cells in each corresponding well in the 96-well tissue culture plate using a multichannel pipette. VC is virus control and CC is cell control wells

9. Perform twofold serial dilutions on added serum samples by transferring $60 \mu \mathrm{L}$ progressively from row to row (i.e., Al to $\mathrm{Bl}$; $\mathrm{Bl}$ to $\mathrm{Cl}$; etc. up to $\mathrm{Gl}$ to $\mathrm{Hl}$ ) using a multichannel pipette (Fig. 3).

10. During each dilution step mix well by pipetting eight times up and down ( see Note 14).

11. Discard the final $60 \mu \mathrm{L}$ after row $\mathrm{H}$.

12. Prepare virus suspension in pre-warmed $\mathrm{M}-2$ so that $60 \mu \mathrm{L}$ contains $120 \mathrm{TCID}_{50}$ (i.e., $2 \times 10^{3} \mathrm{TCID}_{50} / \mathrm{mL}$ ). Approximately $6 \mathrm{~mL} /$ plate is needed (see Note 18 ).

13. Add $60 \mu \mathrm{L}$ diluted virus to all wells except wells in columns 12 (CC wells).

14. Add $60 \mu \mathrm{L}$ pre-warmed M-2 to all CC wells (i.e., columns 12).

15. Incubate the serum-virus mixtures for $1 \mathrm{~h}$ in $37^{\circ} \mathrm{C}$ incubator with $5 \% \mathrm{CO}_{2}$.

16. Remove the 96-well tissue culture plate containing confluent Vero E6 cells and aspirate the media ( see Note 15). 
17. Transfer $100 \mu \mathrm{L}$ from the U-shaped 96-well plate to the cells in each corresponding well in the 96-well tissue culture plate using a multichannel pipette (see Note 14).

18. Incubate the 96 -well tissue culture plate in $37^{\circ} \mathrm{C}$ incubator with $5 \% \mathrm{CO}_{2}$ for 3 days (see Note 11 ).

19. Calculate $\mathrm{MN}_{50}$ or $\mathrm{MN}_{100}$ titers of each serum sample as the highest serum dilution that completely protect the cells from $\mathrm{CPE}$ in half or all wells, respectively.

\section{Notes}

1. The water bath is a potential source of contamination. To reduce the risk of contamination, keep the O-ring and cap of the cryovial out of the water.

2. Frozen cell stocks contain dimethyl sulfoxide (DMSO), which is harmful to the cells, and it should be diluted and removed after thawing the cells and before transferring the cells to tissue culture flasks.

3. After centrifugation, check the clarity of the supernatant and visibility of a complete pellet.

4. Different volumes and culture vessels could be used. It is better to initiate Vero E6 cells culture in a T25 tissue culture flask. If using a T25 tissue culture flask, re-suspend the cells in $5 \mathrm{~mL}$ media, and if using T75 tissue culture flask, re-suspend the cells in $10 \mathrm{~mL}$ media.

5. Vero E6 cells recover slowly after freezing and may take more than a week before they are ready to be passaged. It may take 2-3 passages before the Vero E6 cells reach their normal growth rate.

6. It is important to monitor Vero E6 cells and to subculture them once confluent. Depending on the number of seeded cells and the size of the used flask, Vero E6 cells usually need to be passaged 2-3 times per week.

7. To harvest or maintain Vero E6 cells, remove media from the flask, wash the cell monolayer gently with $3-5 \mathrm{~mL}$ of sterile pre-warmed DPBS without calcium or magnesium, and discard the used washing solution. Add $2-5 \mathrm{~mL}$ pre-warmed $1 \times$ trypsin-EDTA in DPBS without calcium or magnesium to the cell monolayer and incubate for $5-10 \mathrm{~min}$ at $37^{\circ} \mathrm{C}, 5 \% \mathrm{CO}_{2}$ to detach cells (incubation may vary, so check the cells every 2-3 min). After cells are detached, add $5 \mathrm{~mL}$ pre-warmed M-10 to the flask to inactivate trypsin activity, and collect detached cells in $15 \mathrm{~mL}$ sterile falcon tube. Make sure to centrifuge the collected cells and discard the supernatant. 
Then, add new $1-2 \mathrm{~mL}$ pre-warmed $\mathrm{M}-10$ and re-suspend the cells by pipetting up and down using $1 \mathrm{~mL}$ pipette to make a homogenous cell suspension.

8. Change the seeding density of cells when cells are under or over confluent.

9. Use, Sterile $0.22 \mu \mathrm{m}, \gamma$-irradiated syringe filters with small membrane diameter if sample volume is small for minimal sample loss.

10. Multiplicity of infection (MOI) of $0.001-0.1$ could be used if titer is known. It is suggested to use small culture vessels (T25 tissue culture flask) for virus isolation from positive samples and larger culture vessels (T175 tissue culture flask) for virus amplification.

11. CPE could be strain specific, and it depends on the strain and starting titer of the seed virus.

12. Each tube should be used once only to avoid freezing and thawing as this can significantly decrease the virus titer. Use $1 \mathrm{~mL}$ aliquots tubes for virus amplification.

13. Other dilutions such as $1 / 2 \log 10$ dilution could be used.

14. Change pipette tips between wells.

15. Avoid cell drying by minimizing the time between media aspiration and adding the virus inoculum or the serum-virus mixtures.

16. Alternatively, remove media from cells and fix cells with $100 \mu \mathrm{L}$ ice-cold $4 \%$ paraformaldehyde for $5 \mathrm{~min}$ at room temperature. Remove fixative and stain cells with $100 \mu \mathrm{L}$ crystal violet $(0.05 \% \mathrm{w} / \mathrm{v})$ in $20 \%$ methanol for $30 \mathrm{~min}$ at room temperature, and wash cells in tap water. Score wells as positive for MERS$\mathrm{CoV}$ (i.e., no crystal violet) or negative for MERS-CoV (i.e., cells are stained with crystal violet).

17. For each serum sample, $12 \mu \mathrm{L}$ are needed per single test; however, sera should be tested in at least duplicates, so more volume is needed. Different plates should be used when testing neutralization against different virus strains.

18. Set up back virus titration to ensure working virus concentration is accurate. Starting with the working virus dilution $\left(2 \times 10^{3} \mathrm{TCID}_{50} / \mathrm{mL}\right)$, prepare twofold serial dilution in pre-warmed M-2 in a final volume of $60 \mu \mathrm{L}$ (4 replicates per dilution). After dilution, add $60 \mu \mathrm{L}$ of pre-warmed M-2 to each well for a final volume of $120 \mu \mathrm{L}$ and incubate for $1 \mathrm{~h}$ in $37^{\circ} \mathrm{C}$ incubator with $5 \% \mathrm{CO}_{2}$. Then, transfer $100 \mu \mathrm{L}$ to Vero E6 cells in 96-well tissue culture plate and incubate for 3 days in $37^{\circ} \mathrm{C}$ incubator with $5 \% \mathrm{CO}_{2}$. After incubation, examine the plate for $\mathrm{CPE}$ and calculate $\mathrm{TCID}_{50}$ using Reed-Muench formula. 
Acknowledgment

This work was supported by King Abdulaziz City for Science and Technology (KACST) through the MERS-CoV research grant program (number 09-1 to AMH), which is a part of the Targeted Research Program.

\section{References}

1. Zaki AM, van Boheemen S, Bestebroer TM et al (2012) Isolation of a novel coronavirus from a man with pneumonia in Saudi Arabia. N Engl J Med 367:1814-1820. https://doi.org/ 10.1056/NEJMoa1211721

2. Alagaili AN, Briese T, Mishra N et al (2014) Middle East respiratory syndrome coronavirus infection in dromedary camels in Saudi Arabia. MBio 5:e00884-e00814. https://doi.org/10. $1128 / \mathrm{mBio} .00884-14$

3. Azhar EI, El-Kafrawy SA, Farraj SA et al (2014) Evidence for camel-to-human transmission of MERS coronavirus. $\mathrm{N}$ Engl J Med 370:2499-2505. https://doi.org/10.1056/ NEJMoal401505

4. Poissy J, Goffard A, Parmentier-Decrucq E et al (2014) Kinetics and pattern of viral excretion in biological specimens of two MERSCoV cases. J Clin Virol 61:275-278. https:// doi.org/10.1016/j.jcv.2014.07.002

5. Müller MA, Meyer B, Corman VM et al (2015) Presence of Middle East respiratory syndrome coronavirus antibodies in Saudi Arabia: a nationwide, cross-sectional, serological study. Lancet Infect Dis 15:559-564. https://doi. org/10.1016/S1473-3099(15)70090-3

6. Corman VM, Albarrak AM, Omrani AS et al (2016) Viral shedding and antibody response in 37 patients with Middle East respiratory syndrome coronavirus infection. Clin Infect Dis 62:477-483. https://doi.org/10.1093/ cid/civ951

7. Zhao J, Alshukairi AN, Baharoon SA et al (2017) Recovery from the Middle East respiratory syndrome is associated with antibody and T-cell responses. Sci Immunol 2:eaan5393. https://doi.org/10.1126/sciimmunol. aan5393

8. Al-Amri SS, Abbas AT, Siddiq LA et al (2017) Immunogenicity of candidate MERS-CoV DNA vaccines based on the spike protein. Sci Rep 7:44875. https://doi.org/10.1038/ srep44875

9. Perera RA, Wang P, Gomaa MR et al (2013) Seroepidemiology for MERS coronavirus using microneutralisation and pseudoparticle virus neutralisation assays reveal a high prevalence of antibody in dromedary camels in Egypt, June 2013. Euro Surveill 18:20574
10. Reusken C, Mou H, Godeke GJ et al (2013) Specific serology for emerging human coronaviruses by protein microarray. Euro Surveill 18:20441

11. Al-Abdallat MM, Payne DC, Alqasrawi S et al (2014) Hospital-associated outbreak of Middle East respiratory syndrome coronavirus: a serologic, epidemiologic, and clinical description. Clin Infect Dis 59:1225-1233. https://doi. org/10.1093/cid/ciu359

12. Hemida MG, Perera RA, Al Jassim RA et al (2014) Seroepidemiology of Middle East respiratory syndrome (MERS) coronavirus in Saudi Arabia (1993) and Australia (2014) and characterisation of assay specificity. Euro Surveill 19:20828

13. Kleine-Weber H, Elzayat MT, Wang L et al (2015) Inability of rat DPP4 to allow MERS$\mathrm{CoV}$ infection revealed by using a VSV pseudotype bearing truncated MERS-CoV spike protein. Arch Virol 160:2293-2300. https:// doi.org/10.1128/JVI.01381-18

14. Park SW, Perera RA, Choe PG et al (2015) Comparison of serological assays in human Middle East respiratory syndrome (MERS)coronavirus infection. Euro Surveill 20:30042. https://doi.org/10.2807/15607917.ES.2015.20.41.30042

15. Fukushi S, Fukuma A, Kurosu T et al (2017) Characterization of novel monoclonal antibodies against the MERS-coronavirus spike protein and their application in speciesindependent antibody detection by competitive ELISA. J Virol Methods 251:22-29. https:// doi.org/10.1016/j.jviromet.2017.10.008

16. Trivedi S, Miao C, Al-Abdallat MM et al (2017) Inclusion of MERS-spike protein ELISA in algorithm to determine serologic evidence of MERS-CoV infection. J Med Virol 90:367-371. https://doi.org/10.1002/jmv. 24948

17. Hashem AM, Al-Amri SS, Al-Subhi TL et al (2019) Development and validation of different indirect ELISAs for MERS-CoV serological testing. J Immunol Methods 466:41-46. https://doi.org/10.1016/j.jim.2019.01.005

18. Reed LJ, Muench H (1938) A simple method of estimating fifty per cent endpoints. Am J Epidemiol 27:493-497 